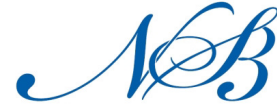

Notulae Scientia Biologicae

\title{
RAPD and ISSR Methods Used for Fingerprinting of Selected Accessions of Viburnum
}

\author{
Marcelina KRUPA-MA£KIEWICZ ${ }^{1}$, Anna BARNIAK ${ }^{1}$, \\ Beata SMOLIK ${ }^{2}$, Miłosz SMOLIK ${ }^{1 *}$ \\ ${ }^{1}$ West Pomeranian University of Technology in Szczecin, Department of Plant Genetics, Breeding and Biotechnology, 17 Stowackiego, 71 -434 Szczecin, Poland; \\ mkrupa@zut.edu.pl;msmolik@zut.edu.pl (correspondingauthor) \\ ${ }^{2}$ West Pomeranian University of Technology in Szczecin, Department of Plant Physiology and Biochemistry, 17 Stowackiego, $71-434$ Szczecin, Poland; \\ bsmolik@zut.edu.pl
}

\begin{abstract}
Randomly amplified polymorphic DNA (RAPD) and inter simple sequence repeat (ISSR) markers were used to investigate genetic variability within thirteen Viburnum species (Viburnum $\times$ hillieri; $V$. dilatatum; Viburnum $\times$ carlcephalum; $V$. opulus; $V$. hupehense; Viburnum $\times$ bodnantense; Viburnum $\times$ burkwoodii; $V$. sieboldii; Viburnum $\times$ globosum 'Jermyns Globe'; V. alnifolium (lantanoides); $V$.plicatum 'Sterile'; V.plicatum f. tomentosum and $V$.plicatum 'Watanabe') of wide geographical distribution, collected in the Dendrological Garden in Przelewice (the north-west part of Poland). Twenty-three RAPD and fourteen ISSR primers generated a total of 690 and 418 reproducible bands, respectively, and 39\% (RAPD) and 55.5\% (ISSR) of them were polymorphic for the two marker systems, which suggest high genetic variability within Viburnum genus. However, high numbers of genotype-specific bands, i.e. 60.9\% (RAPD) and 44.5\% (ISSR), were seen in Viburnum. Genetic similarity assessed within Viburnum species with the RAPD and ISSR analyses ranged from 6 to $42 \%$ and from 6 to $31 \%$, respectively. Both RAPD and ISSR-based dendrograms clustered in five main groups. The Mantel test between two Nei's similarity matrices gave correlation coefficient $\mathrm{r}=0.305^{*}$, showing low correlation between RAPD- and ISSR- based matrices. Thus, both marker systems were equally important for the genetic diversity analysis in Viburnum genus.
\end{abstract}

Keywords: accessions, genetic similarity, polymorphism, variability

\section{Introduction}

Viburnum genus belongs to Caprifoliaceae family and comprises more than 230 species mainly distributed in the temperate and subtropical zones, particularly in Asia and North America. It is divided into eleven sections based on morphological characters and geographical origin (Lobstein et al., 2003). Only two species occur in Poland in the wild: $V$. lantana and $V$. opulus (Bugała, 2000).

Donoghue (1983) found nine of the ten traditionally recognized sections to be monophyletic. It was a result of an analysis which was performed on the basis of a set of morphological traits. The exception was Odontotinus section that contained a clade corresponding to Latin American Oreinotinus section.

Donoghue et al. (2004) distinguished three main suprasectional groups within Viburnum genus. The largest one included sections occurring in Eurasia, Asia and Latin
America, the second one had sections occurring in Asia and the third one included sections of the region of North America and Asia.

Not only according to Donoghue et al. (2004), but also to Winkworth and Donoghue (2004, 2005), DNA sequence analysis can be useful in meticulous research on mutual phylogenetic relationships and the direction of evolution within Viburnum. The researchers stated that most of the already recognized sections are monophyletic. Odontotinus section is an exception, as it was divided into the purple-fruited New World clade, where Latin American Oreinotinus section is nested, and Old World clade, closely related Viburnum cylindricum (Megalotinus section) and the New World clade - Viburnum acerifolium (Donoghue et al., 2004).

The collection of various, often unique Viburnum objects of the Dendrological Garden in Przelewice is a place where many systematically distant objects, including hybrids 
and accessions, are gathered. As an extraordinary valuable source of Viburnum genes, it enables morphological, phenological and molecular analyses. It can be used for genotyping and description of mutual genetic relationships with the use of different methods, including those based on PCR amplification with randomly amplified polymorphic DNA (RAPD), as well as inter simple sequence repeats (ISSR) (Hyvönen, 2010; Poczai and Hyvönen, 2010; Smolik et al., 2010; Sharma et al., 2009; Shneyer, 2009, Smolik and Krzysztoszek (2010)). The first one amplifies DNA using 10-mer primers, while the second one involves amplification of DNA sequence between two adjacent and inversely oriented microsatellites usually by using 18-24-mer primers (Williams et al., 1990; Ziętkiewicz et al., 1994). RAPD and ISSR are popular DNA fingerprinting methods because they are quick, inexpensive, highly polymorphic and also they do not require any sequence information about the under study genome (Gajera et al., 2011; Yüzbaşioğlu et al., 2011).

Thus, in the present study, we used both RAPD and ISSR methods to perform fingerprinting and examine the level of genetic similarity within Viburnum accessions, and to assess to what extent the results of the molecular analysis will be helpful in the assessment of genetic relationships between the selected accessions of Viburnum genus collected in the Dendrological Garden in Przelewice.

\section{Materials and methods}

The research material comprised 13 objects of Viburnum sp. of different origin, a part of the genus collection gathered in the Dendrological Garden in Przelewice (the north-west part of Poland). The research included: Viburnum $\times$ billieri - hybrid of $V$. erubescens $\times V$. henryi, $V$. dilatatum, Viburnum $\times$ carlcephalum - hybrid of $V$. carlesii $\times V$. macrocephalum, $V$. opulus, $V$. hupehense, Viburnum $\times$ bodnantense - hybrid of $V$. farreri $\times V$. grandiflorum, Viburnum $\times$ burkwoodii - hybrid of $V$. carlesii $\times V$. tiule, $V$. sieboldii, Viburnum $\times$ globosum 'Jermyns Globe' - hybrid of $V$. davidii $\times V$. calvum, $V$. plicatum $\mathrm{f}$. tomentosum, $V$. alnifolium (lantanoides), $V$. plicatum 'Sterile' and $V$.plicatum 'Watanabe'.

\section{Plant DNA extraction}

Fresh leaves were collected from 13 Viburnum genotypes (selected as one plant per genotype). All leaf samples were ground in liquid nitrogen using a mortar and a pestle to fine powder. Total genomic DNA was extracted using a Genomic Mini AX Plant kit from $100 \mathrm{mg}$ of fresh leaf material. Contaminating RNA was removed by digestion with RNase $\mathrm{A}\left(20 \mathrm{mg} \cdot \mathrm{cm}^{-3}\right)$.

\section{RAPD amplification}

PCR amplification was performed with a set of 23 decamer primers (professional kit) according to the protocol described by Williams et al. (1990). Amplifications were performed in $25 \mu \mathrm{l}$ reaction volume containing $10 \times$ PCR buffer with $\left(\mathrm{NH}_{4}\right)_{2} \mathrm{SO}_{4}(750 \mathrm{mM}$ Tris- $\mathrm{HCl} \mathrm{pH}$ $8.3,200 \mathrm{mM}\left(\mathrm{NH}_{4}\right)_{2} \mathrm{SO}_{4}, 0.1 \%$ Tween 20$), 0.2 \mathrm{mM}$ of dNTPs, $2.0 \mathrm{mM} \mathrm{MgCl}_{2}, 0.25 \mu \mathrm{M}$ of primer, 1.0 unit of Taq
DNA polymerase enzyme (Thermo Scientific) and 30-40 ng of template DNA. Amplifications were performed in an Eppendorf Master cycler 5333. The program of thermal cycling was as follows: initial activation step at $95^{\circ} \mathrm{C}$ for 15 min, followed by 34 cycles for $1 \mathrm{~min}$ at $94^{\circ} \mathrm{C}, 1 \mathrm{~min}$ at $36^{\circ} \mathrm{C}$ and $2 \mathrm{~min}$ at $72^{\circ} \mathrm{C}$, with the final extension step at $72^{\circ}$ for $10 \mathrm{~min}$. The amplification was conducted by final extension at $72^{\circ} \mathrm{C}$ for $5 \mathrm{~min}$.

ISSR amplification

ISSR amplifications were performed with a set of 14 ISSR primers (collection of the University of British Columbia, Canada). Reaction mixtures $(25 \mu \mathrm{l})$ contained: $10 \times \mathrm{PCR}$ buffer with $\left(\mathrm{NH}_{4}\right)_{2} \mathrm{SO}_{4}(750 \mathrm{mM}$ Tris- $\mathrm{HCl} \mathrm{pH}$ $8.3,200 \mathrm{mM}\left(\mathrm{NH}_{4}\right)_{2} \mathrm{SO}_{4}, 0.1 \%$ Tween 20$), 2.0 \mathrm{mM} \mathrm{MgCl}$, 1 out of 14 different $0.2 \mu \mathrm{M}$ primers, $0.2 \mathrm{mM}$ of each dNTP (Thermo Scientific), 1.0 unit of Taq DNA polymerase (Thermo Scientific) and $100 \mathrm{ng}$ genomic DNA. Amplification was performed in an Eppendorf Master cycler 5333 using the following program: initial denaturation at $94^{\circ} \mathrm{C}$ for $7 \mathrm{~min}, 35$ cycles of $30 \mathrm{~s}$ at $94^{\circ} \mathrm{C}$, $50 \mathrm{~s}$ at annealing temperature, $2 \mathrm{~min}$ at $72^{\circ} \mathrm{C}$ and $7 \mathrm{~min}$ at $72^{\circ} \mathrm{C}$ for final extension. The annealing temperature was adjusted according to the $T_{m}$ of the primers used in the reaction.

\section{Electrophoresis}

PCR products were mixed with $6 \times$ Orange Loading Dye Solution and analyzed by electrophoresis (SubCell GT). O'RangeRuler 200 bp DNA Ladder (3000-200 bp) was used as a size marker. Amplified products were loaded on $1.5 \%$ agarose gel and separated in $1 \times$ TBE buffer. A constant voltage of 100 was provided for $2 \mathrm{~h}$. DNA fragments were visualized under UV light after staining with ethidium bromide $\left(5.0 \mathrm{mg} \cdot \mathrm{cm}^{-3}\right)$. The RAPD and ISSR bands were scored as present (1) or absent (0), each of which was treated as an independent character regardless of its intensity.

\section{Data analysis}

Data analyses were conducted using the PhylTool software (Buntjer, 2001). Similarity matrix for both RAPD and ISSR primers was constructed using the Nei's similarity coefficient values to find genotypic relationships (Nei and $\mathrm{Li}, 1979)$. The $0 / 1$ matrix data obtained from RAPD and ISSR primers were arranged to get separate similarity matrices which were subjected to UPGMA (unweighted pair-group method with arithmetic averages) analysis to generate a dendrogram and compared using the Mantel matrix correspondence test (XLSTAT software). The strength of the internal branches from the resulting tree was tested with the Treecom bootstrap analysis application using 2,000 resamplings (Van de Peer and De Wachter, 1994). The matrices were also compared using the Mantel's test (Mantel, 1967) for matrix correspondence.

\section{Results and discussion}

RAPD analysis

For thirteen examined Viburnum objects, altogether 690 loci were amplified (1160 amplicons), including 271 (39\%) 
294

polymorphic ones, 418 (60.9\%) accession-specific, and only $1(0.1 \%)$ monomorphic (Tab. 1). Altogether, on average ca. 30 loci were amplified in a reaction with one RAPD primer (including 12 polymorphic and 18 accession-specific loci). The length of the amplified loci ranged from 2530 (OPW_02) to $190 \mathrm{bp}$ (OPM_05). The greatest number of loci $(45)$ was obtained in a reaction with primer OPW 12 , and the lowest (20) with primer OPW_03.

\section{Monomorphic loci}

Among the 23 RAPD primers used in the experiment, a monomorphic product of the length of $190 \mathrm{bp}$ was amplified only in a reaction with primer OPM_05 (Tab. 1).

\section{Polymorphic loci}

The examined Viburnum genotypes exhibited a high level of genetic diversity (Fig. 1). Among all the amplified RAPD loci, 271 (39\%) were described as polymorphic (Tab. 1). The greatest number (19) was amplified in a reaction with primer OPW_02, and the least (6) - with primers OPW_09 and OPW_-10.

\section{Genotype-specific loci}

$60.9 \%$ of amplified loci were described as accessionspecific (Tab. 2). For each examined subject, accessionspecific RAPD products were amplified. The greatest number (28) was generated in a reaction with RAPD primer OPW_12, and the lowest number (11) - with primer OPA_1 (Tab. 2). The highest number (47) of products of this type was observed for $V . \times$ globosum 'Jermyns Globe' accession, and the lowest number (14 genotype-specific) for $V$. dilatatum species (Tab. 2). They were amplified in reactions with 20 and 10 RAPD primers, respectively.

\section{ISSR analysis}

Assessment of genetic diversity between thirteen Viburnum genotypes was carried out in a reaction with fourteen ISSR primers (Tab. 1). Altogether, 418 ISSR loci (873 amplicons) were amplified in the experiment, of which $232(55.5 \%)$ were described as polymorphic and 186 (44.5\%) as genotype-specific (Tab. 1). Monomorphic products were not amplified. In a reaction with one primer, on average 30 ISSR loci were amplified, of which 17 were polymorphic, and 13 - genotype-specific (Tab. 1). Their length ranged from $3130 \mathrm{bp}$ (primer 863) to $230 \mathrm{bp}$ (primer 816 and 863 ).

\section{Polymorphic loci}

A relatively wide range of variability was observed between the examined Viburnum objects (Fig. 1), resulting from the presence of PCR products, determined as polymorphic (55.5\%), in electropherograms. Reactions with primers 818,848 and 851 generated the highest number of

Tab. 1. Characteristic of generated RAPD and ISSR products for 13 genotypes of Viburnum

\begin{tabular}{|c|c|c|c|c|c|c|c|c|c|c|c|c|c|c|c|c|c|c|c|c|}
\hline \multicolumn{4}{|c|}{ Technique, primers etc. } & \multicolumn{3}{|c|}{ Loci } & \multicolumn{13}{|c|}{ Genotypes of Viburnum } & 2 \\
\hline 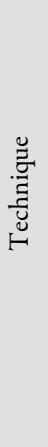 & 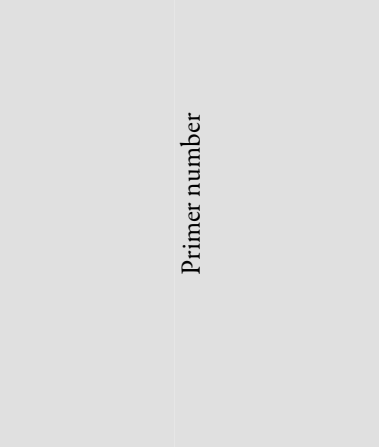 & 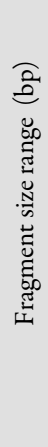 & 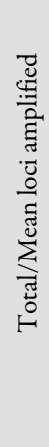 & 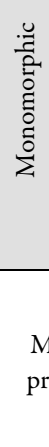 & 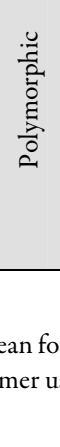 & 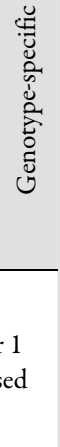 & 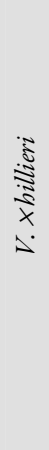 & 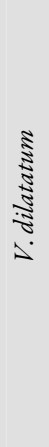 & 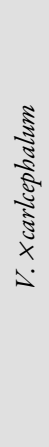 & 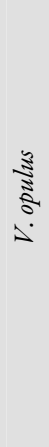 & 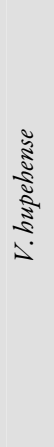 & 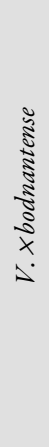 & 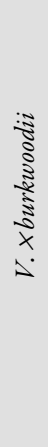 & 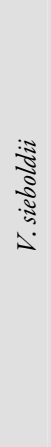 & 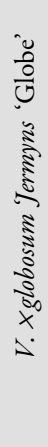 & 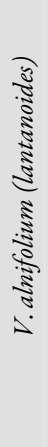 & 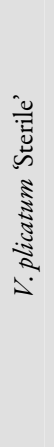 & 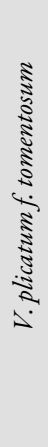 & 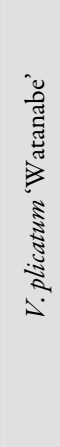 & 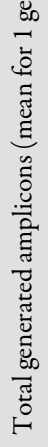 \\
\hline ఏ & $\begin{array}{l}\text { OPA_1, OPA_2, OPA_3, } \\
\text { OPA_4, OPG_14, OPJ_01, } \\
\text { OPJ_13, OPM_01, OPM_02, } \\
\text { OPM_03, OPM_05, OPM_12, } \\
\text { OPW_01, OPW_02, OPW_03, } \\
\text { OPW_05, OPW_07, OPW_08, } \\
\text { OPW_08, OPW_09, OPW_10, } \\
\text { OPW_17, OPW_13, OPW_1 }\end{array}$ & 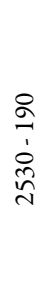 & $\frac{\text { }}{\stackrel{\circ}{\circ}}$ & $\begin{array}{l}\frac{\partial}{2} \\
\hat{e}\end{array}$ & 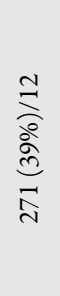 & 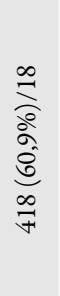 & $\infty$ & N & $+\infty$ & à & $\infty$ & $\approx$ & $\stackrel{\circ}{\circ}$ & $\stackrel{\cong}{=}$ & $\stackrel{\cong}{=}$ & ஓ & $\hat{\varrho}$ & $\infty$ & $\hat{a}$ & $\begin{array}{l}\stackrel{i}{n} \\
\stackrel{0}{0} \\
=\end{array}$ \\
\hline 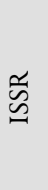 & $\begin{array}{l}802,809,815,816,817,818,821, \\
827,834,837,845,848,851,863\end{array}$ & 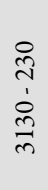 & $\begin{array}{l}0 \\
\frac{n}{\infty} \\
\vec{F}\end{array}$ & $\circ$ & 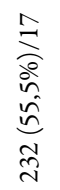 & 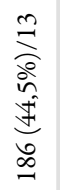 & $\hat{n}$ & $\Re$ & $\hat{\imath}$ & $\bar{n}$ & $\cong$ & 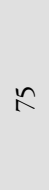 & $\tilde{\sigma}$ & R & જે & $\overleftarrow{\sigma}$ & 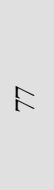 & જ) & $i$ & 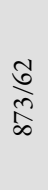 \\
\hline
\end{tabular}


Tab. 2. Genotype-specific RAPD products generated for 13 genotypes of Viburnum investigated (profiled)

\begin{tabular}{|c|c|}
\hline Genotype & $\begin{array}{l}\text { Primers and genotypes-specific } \\
\text { RAPD products }\end{array}$ \\
\hline$V . \times$ hillier & 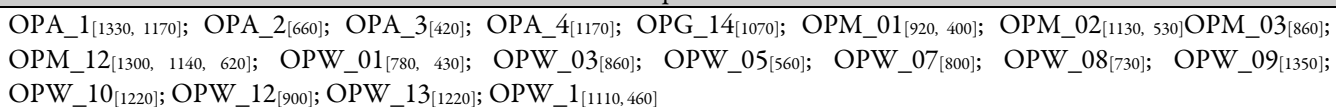 \\
\hline V. dilatatum & $\begin{array}{l}\text { OPA_3[1130]; OPG_14[1310, 740]; OPJ_13[760]; OPM_01[530]; OPM_12[760]; OPW_05[570]; OPW_07[300]; OPW_09[860]; } \\
\text { OPW_10[1210,460]; OPW_12[1060,720,330] }\end{array}$ \\
\hline$V . \times$ carlcephalum & 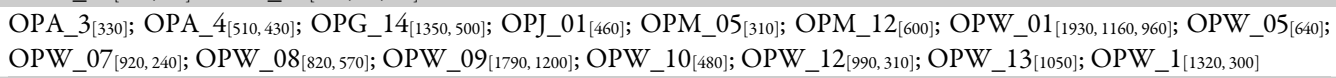 \\
\hline V. opulus & 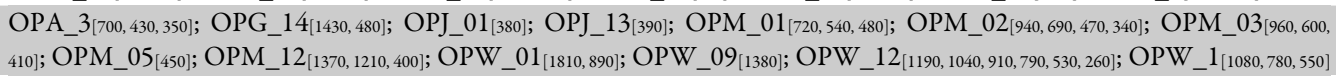 \\
\hline$V$. hupehense & 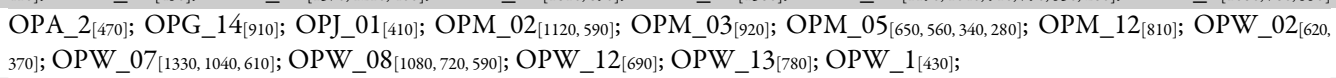 \\
\hline$V . \times$ bodnantense & $\begin{array}{l}\text { OPA_1[1370]; OPA_2[940, 670]; OPA_3[280]; OPA_4[1190]; OPG_14[970, 760]; OPJ_01 }[610] ; \text { OPJ_13[840, 550]; OPM_01 }{ }_{[990,440]} \text {; } \\
\text { OPM_02[980]; OPM_05[480]; OPM_12[800, 700, 260]; OPW_05[600]; OPW_07[970]; OPW_09[1690, 900]; OPW_10[1050, 660, 430]; } \\
\text { OPW_13[1000]; OPW_1[800,420] }\end{array}$ \\
\hline$V . \times$ burkwoodii & 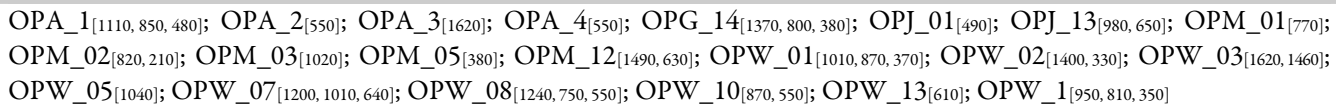 \\
\hline V. sieboldii & 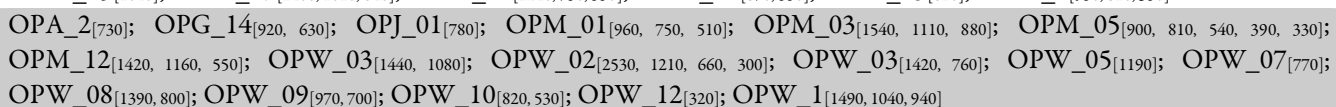 \\
\hline $\begin{array}{l}V . \times \text { globosum 'Jermyns } \\
\text { Globe' }\end{array}$ & 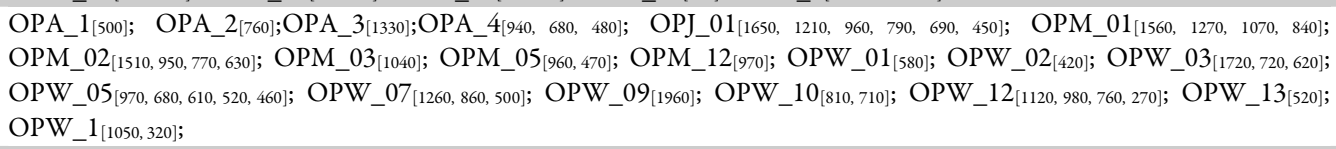 \\
\hline V.alnifolium (Lantanoides) & 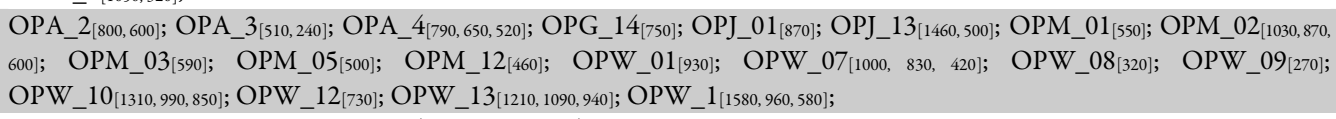 \\
\hline V.plicatum 'Sterile' & 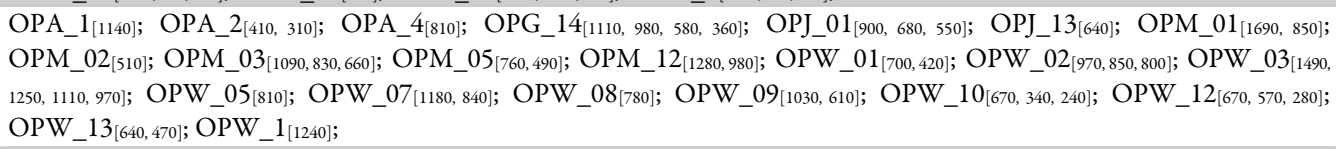 \\
\hline$V \cdot$ plicatum f. tomentosum & 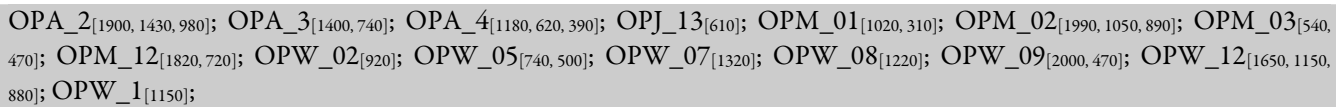 \\
\hline V.plicatum 'Watanabe' & 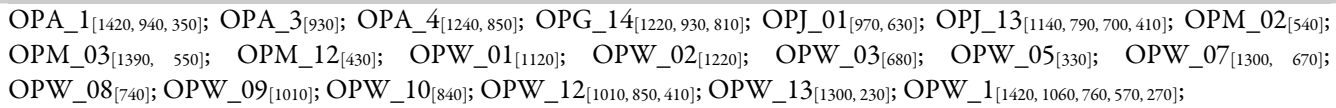 \\
\hline
\end{tabular}

polymorphic ISSR products (26 and 24) and their length ranged from 2650 to $440 \mathrm{bp}$.

Genotype-specific loci

Analysis of electropherograms of the examined Viburnum genotypes described 186 (44.5\%) loci as accessionspecific (Tab. 1). The most loci (20 and 18) were amplified in reactions with primers: 837,818 and 863 (Tab. 3). The least loci (8) were noted for $V$. opulus species. Analysis of the sequence of primers used for DNA amplification of the examined Viburnum forms revealed that the highest number of genotype-specific ISSR loci (20) was amplified with primer 837 [(AC) $\left.{ }_{8} Y G\right]$, while the lowest number (6) was obtained with the use of primer $834\left[\left(\mathrm{AG}_{8} \mathrm{GT}\right]\right.$.

Polymorphic loci

A relatively wide range of variability was observed between the examined Viburnum objects (Fig. 1), resulting from the presence of PCR products, determined as polymorphic (55.5\%), in electropherograms. Reactions with primers 818,848 and 851 generated the highest number of polymorphic ISSR products (26 and 24) and their length ranged from 2650 to $440 \mathrm{bp}$.

Genotype-specific loci
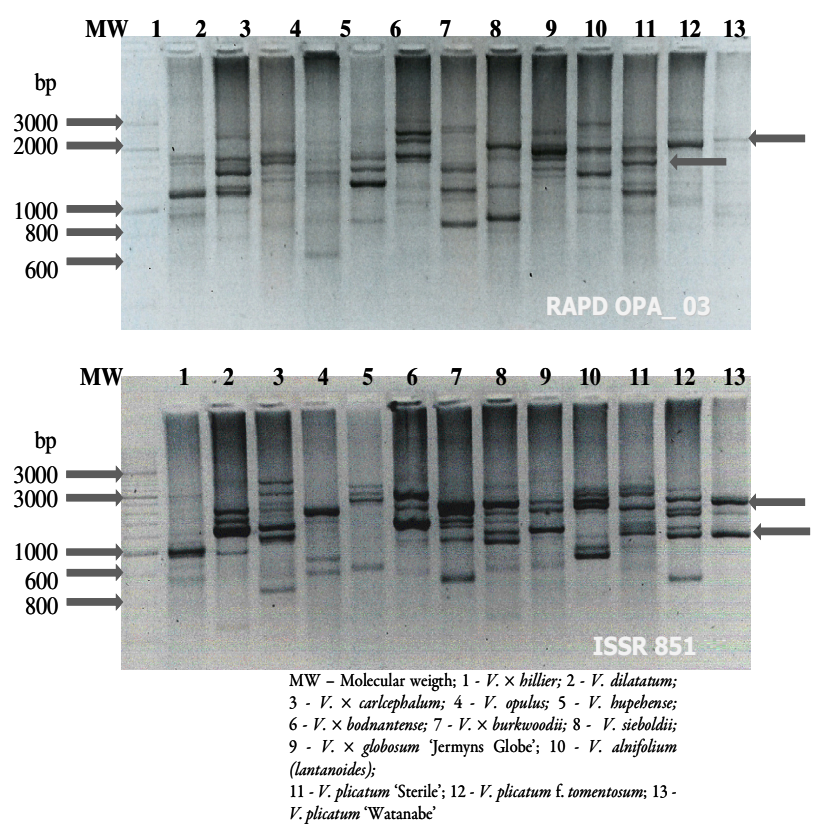

Fig. 1. PCR amplification profiles of 13 Viburnum genotypes. (a) RAPD primer no. OPA_03, and (b) ISSR primer no. 851 


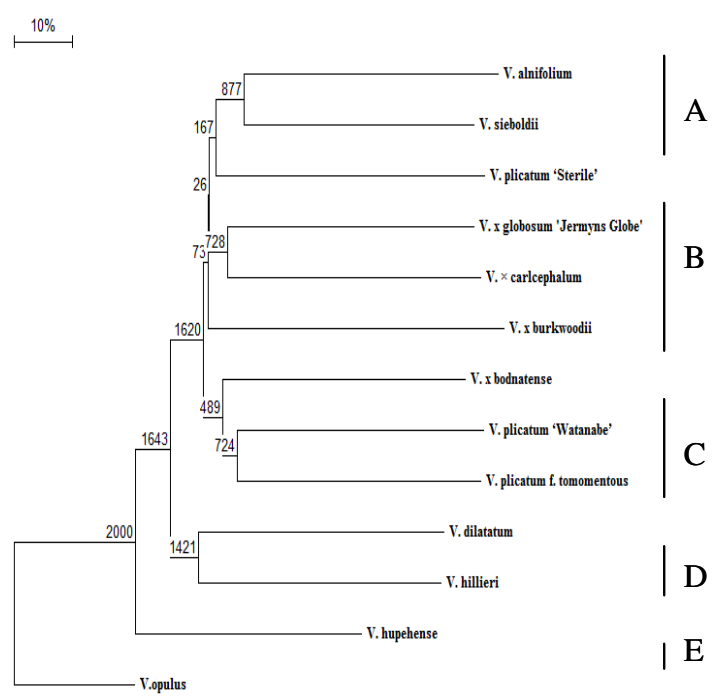

a) RAPD

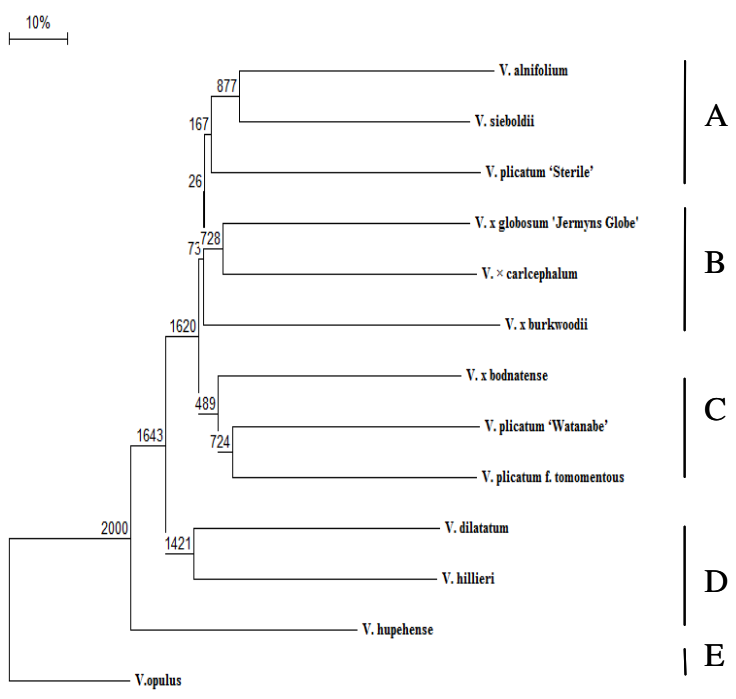

b) ISSR

$\mathrm{r}_{(\mathrm{RAPD} \text { ISSR })}=0.305^{*} \mathrm{p}$-value (two tailed) $=0.015$

Fig. 2. Dendrograms generated using unweighted pair group method with arithmetic average analysis, showing relationship between Viburnum genotypes, using RAPD a) and ISSR b) data. The number at the forks indicate the confidence limits for the grouping of those species in a branch occurred, based on 2.000 pseudoreplications in bootstrap analysis

Analysis of electropherograms of the examined Viburnum genotypes described 186 (44.5\%) loci as accession-specific (Tab. 1). The most loci (20 and 18) were amplified in reactions with primers: 837,818 and 863 (Tab. 3). The least loci (8) were noted for $V$. opulus species. Analysis of the sequence of primers used for DNA amplification of the examined Viburnum forms revealed that the highest number of genotype-specific ISSR loci (20) was amplified with primer 837 [( $\left.\mathrm{AC})_{8} \mathrm{YG}\right]$, while the lowest number (6) was obtained with the use of primer 834 $\left[\left(\mathrm{AG}_{8} \mathrm{GT}\right]\right.$.

Phylogenetic analysis

On the basis of the genetic profiles obtained with the RAPD and ISSR techniques, respectively two dendrograms of phylogenetic similarity were generated for the thirteen examined Viburnum genotypes (Fig. 2a, b). Genetic similarity assessed between the accessions of Viburnum with the RAPD and ISSR analyses ranged from 6 to $42 \%$ and from 6 to $31 \%$, respectively. The thirteen examined genotypes of Viburnum were grouped in five clusters according to both RAPD and ISSR data. Clustering of genotypes within groups was similar when RAPD- and ISSR- derived dendrograms were compared. $V$. dilatatum, $V$. hillieri and also $V$. plicatum 'Watanabe' and $V$. plicatum $\mathrm{f}$. tomentosum were clustered in similar groups when RAPDand ISSR- derived dendrograms were compared. The correlation between the matrices of cophenetic correlation values for the dendrogram based on RAPD and ISSR data was low $\left(r=0.305^{*}\right)$, yet significant $(p$-value $=0.015)$.

\section{Discussion}

Molecular markers have been widely used to evaluate genetic variability within and between species for several
Tab. 3. Genotype-specific ISSR products generated for 13 genotypes of Viburnum

\begin{tabular}{|c|c|}
\hline Genotype & $\begin{array}{l}\text { Primers and genotype-specific } \\
\text { ISSR products }\end{array}$ \\
\hline V. $\times$ hillieri & $\begin{array}{l}816_{[600]} ; 818_{[1400] ;} 821_{[2600]} ; 827_{[880,720]} ; 837 \\
{[1000,890,460] ; 845_{[720]} ; 851_{[1210]} ; 863_{[860]}}\end{array}$ \\
\hline V. dilatatum & 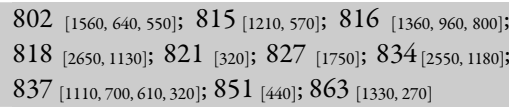 \\
\hline$V . \times$ carlcephalum & 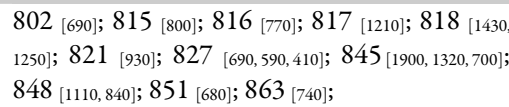 \\
\hline V.opulus & $\begin{array}{l}802_{[450]} ; 809_{[630]} ; 815_{[930]} ; 818{ }_{[610]} ; 834_{[790]} \\
845{ }_{[550]} ; 848[640] ; 851_{[810]} ;\end{array}$ \\
\hline$V$. hupehense & $\begin{array}{l}802_{[1000,620]} ; 809_{[1100,850,760]} ; 815_{[1590,600]}^{618} 8818 \\
[1020] ; 82]_{[330]} ; 837_{[560]} ; 851_{[2290,830]} ; 863_{[1100]} ;\end{array}$ \\
\hline$V . \times$ bodnantense & $\begin{array}{l}817[1460,1120] ; 821[2460] ; 827[370] ; 837[1640,1130, \\
660,290] ; 845[1600] ; 848[2970] ; 851[2580,1950] ;\end{array}$ \\
\hline$V . \times$ burkwoodii & 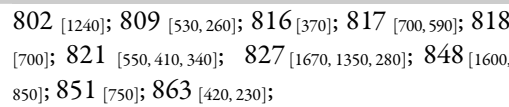 \\
\hline V. sieboldii & 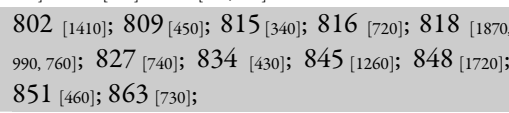 \\
\hline $\begin{array}{l}V . \times \text { globosum } \\
\text { 'Jermyns Globe' }\end{array}$ & $\begin{array}{l}802_{[460]} ; 809_{[540,490,400] ;} 815_{[620]} ; 816_{[280] ;} 818 \\
{[980,870,420] ; 837_{[1540,450]} ; 81_{[2850]}}\end{array}$ \\
\hline $\begin{array}{l}\text { V. alnifolium } \\
\text { (lantanoides) }\end{array}$ & $\begin{array}{l}802[740] ; 815[670] ; 818[520,450] ; 821[720] ; 827 \\
{[2450,1640,1440] ; 837[1820,820] ; 848[2600,1590] ; 863} \\
{[660] ;}\end{array}$ \\
\hline V. plicatum 'Sterile' & 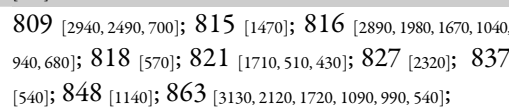 \\
\hline $\begin{array}{l}V \cdot \text { plicatum } \mathrm{f} . \\
\text { tomentosum }\end{array}$ & $\begin{array}{l}815[310] ; 816[4600] ; 817[28330,1870,1250,750] ; 818 \\
{[910] ; 821[[740] ; 827[560] ; 834[1350,450] ; 837[1290} \\
1160,620] ; 851[710] ; 863[520] ;\end{array}$ \\
\hline $\begin{array}{l}\text { V.plicatum } \\
\text { 'Watanabe' }\end{array}$ & $\begin{array}{l}817_{[1710,1000,920] ;} 821_{[1250]} ; 82{ }_{[790]} ; 848_{[2090} \\
1000] ; 863_{[1210,650]}\end{array}$ \\
\hline
\end{tabular}


Tab. 4. Similarity matrix of 13 Viburnum genotypes based on RAPD and ISSR markers

\begin{tabular}{|c|c|c|c|c|c|c|c|c|c|c|c|c|c|}
\hline RAPD & 1 & 2 & 3 & 4 & 5 & 6 & 7 & 8 & 9 & 10 & 11 & 12 & 13 \\
\hline V. $\times$ hillieri & 1.00 & 0.42 & 0.29 & 0.22 & 0.22 & 0.20 & 0.11 & 0.09 & 0.15 & 0.10 & 0.06 & 0.09 & 0.06 \\
\hline$V$. dilatatum & 0.28 & 1.00 & 0.28 & 0.23 & 0.27 & 0.23 & 0.15 & 0.06 & 0.12 & 0.07 & 0.06 & 0.08 & 0.11 \\
\hline V. $\times$ carlcephalum & 0.18 & 0.17 & 1.00 & 0.31 & 0.34 & 0.20 & 0.07 & 0.11 & 0.13 & 0.10 & 0.15 & 0.07 & 0.12 \\
\hline V. opulus & 0.17 & 0.19 & 0.20 & 1.00 & 0.34 & 0.29 & 0.17 & 0.15 & 0.17 & 0.07 & 0.12 & 0.10 & 0.07 \\
\hline$V$. hupehense & 0.17 & 0.26 & 0.16 & 0.31 & 1.00 & 0.41 & 0.24 & 0.12 & 0.14 & 0.17 & 0.11 & 0.11 & 0.10 \\
\hline$V . \times$ bodnantense & 0.15 & 0.18 & 0.22 & 0.13 & 0.20 & 1.00 & 0.25 & 0.11 & 0.13 & 0.10 & 0.09 & 0.13 & 0.08 \\
\hline$V . \times$ burkwoodii & 0.12 & 0.12 & 0.17 & 0.12 & 0.06 & 0.20 & 1.00 & 0.21 & 0.12 & 0.11 & 0.13 & 0.14 & 0.11 \\
\hline V. sieboldii & 0.11 & 0.08 & 0.22 & 0.12 & 0.18 & 0.21 & 0.17 & 1.00 & 0.15 & 0.21 & 0.20 & 0.06 & 0.21 \\
\hline V. X globosum 'Jermyns Globe' & 0.10 & 0.11 & 0.26 & 0.13 & 0.15 & 0.18 & 0.15 & 0.17 & 1.00 & 0.21 & 0.18 & 0.10 & 0.07 \\
\hline V. alnifolium & 0.15 & 0.09 & 0.10 & 0.10 & 0.12 & 0.16 & 0.13 & 0.28 & 0.24 & 1.00 & 0.11 & 0.17 & 0.19 \\
\hline V.plicatum 'Sterile' & 0.09 & 0.16 & 0.17 & 0.09 & 0.16 & 0.17 & 0.16 & 0.18 & 0.23 & 0.23 & 1.00 & 0.16 & 0.16 \\
\hline$V$.plicatum f. tomentosum & 0.16 & 0.11 & 0.15 & 0.10 & 0.13 & 0.24 & 0.08 & 0.27 & 0.23 & 0.21 & 0.18 & 1.00 & 0.20 \\
\hline V.plicatum 'Watanabe' & 0.18 & 0.11 & 0.12 & 0.13 & 0.16 & 0.28 & 0.14 & 0.26 & 0.18 & 0.13 & 0.17 & 0.27 & 1.00 \\
\hline
\end{tabular}

reasons, such as delimitation of species, conservation of endangered species, analysis of the population' structure of a species and construction of phylogenetic relationships among species in fungi, plants and animals (Yüzbaşioğlu et al., 2011). The invention of PCR led to the development of fast and inexpensive molecular markers, such as RAPD and ISSR (Arseniuk 2000; Czembor and Sharma et al., 2009; Gajera et al., 2011; Godwin et al., 1997; Williams et al., 1990; Yüzbaşioğlu et al., 2011). Because of the longer primers used, ISSR markers reported to be more reproducible than RAPD markers (Godwin et al., 1997). Since both of them are PCR-based methods, they require only small amounts of template DNA. Furthermore, they do not require any sequence information for primer construction. The main limitation associated with the RAPD and ISSR method is their dominant inheritance. The second main drawback of RAPDs is low reproducibility due to their sensitiveness to reaction conditions. However, they produce repeatable band profiles when reaction conditions are optimized and kept constant (Gillings and Holley 1997, Godwin et al., 1997; Kumar et al., 2009; Williams et al., 1990).

There are few reports on morphological and genetic characterization of Viburnum genus, difficult in systematization, in the literature on the subject matter (Donoghue et al., 2004). The first study on the subject included the analysis of phenotypic and phenological traits
(Donoghue et al., 2004). Another studies used methods based on molecular analysis of DNA variability (Ackerly and Donoghue 1998; Grimm et al., 2006; Pfosser et al., 2002; Suh et al., 2000). Techniques describing the variability of restriction-digested cDNA, as well as analysis of DNA sequences (Donoghue and Sytsma 1993; Donoghue and Baldwin 1993; Donoghue et al., 2004; Winkworth and Donoghue 2004, 2005) were also studied. Then an attempt was made to describe the direction and scale of migration, development and origin of species (Donoghue and Baldwin 1993; Donoghue et al., 2004, Winkworth and Donoghue 2004). In broad terms, the results of the above-presented studies have agreed on the monophyly and non-monophyly of traditionally recognized taxonomic sections, on relationships between several sections, and on species relationships within several sectionlevel clades. However, more accurate understanding of phylogenetic relationships within Viburnum species requires further research on a considerably greater amount of material, as well as supplementation of the research with the use of other available molecular techniques.

In the author's research, genotypic variability of Viburnum $\times$ billieri, $V$. dilatatum, Viburnum $\times$ carlcephalum, $V$. opulus, $V$. hupehense, Viburnum $\times$ bodnantense, Viburnum $\times$ burkwoodii, $V$. sieboldii, Viburnum $\times$ globosum 'Jermyns Globe', $V$. alnifolium, $V$. plicatum 'Sterile', $V$. plicatum f. tomentosum and $V$. plicatum 
298

'Watanabe' was assessed with 14 ISSR and 23 RAPD primers. As a result of the amplifications with the use of the examined Viburnum genotypes, 1160 (RAPD) and 873 (ISSR) amplicons were scored as the effect of amplification of 690 RAPD and 418 ISSR loci, respectively. The length of the amplified products corresponded to the number of products amplified, the number of primers used, and the length of products mostly generated with these methods and presented in papers by Sharma et al. (2009), Williams et al. (1990), Yüzbaşioğlu et al. (2011) and Zietkiewicz et al. (1994).

We demonstrated high genetic variability among the examined Viburnum objects. It was manifested by a great number of products - both polymorphic (39\% for RAPD and $55.5 \%$ for ISSR) and genotype-specific (60.9\% for RAPD and $44.5 \%$ for ISSR) in electropherograms. In only one case a monomorphic product was obtained, present in electrophoretic images of all the examined genotypes, generated in amplification of RAPD primer OPM_ 05. The results prove that the Dendrological Garden in Przelewice is a rich collection of both cultivated and botanical accessions, as well as hybrids of Viburnum species of different origin. Similar results were observed for several other species, such as black gram (Souframanien and Gopalakrishna 2004), where the percentage of polymorphism ranged from 16.6 to 66.6\%; sesame (Sharma et al., 2009), where 56.18 and $66.78 \%$ of polymorphic bands were amplified by both RAPD and ISSR primers, and Lobathallia radiosa (Yüzbaşioğlu et al., 2011), where all the obtained bands were polymorphic.

A high level of genetic polymorphism of Viburnum species was confirmed in a study by Donoghue et al. (2004) and Winkworth and Donoghue (2005), where analysis of ITS sequences and chloroplast trnK intron with the PCR technique, as well as the analysis of sequences of GBSSI genes, were used for examination of evolutionary relations between different species and accessions of Viburnum, migration, development and origin of species. On the basis of the obtained results, Donoghue et al. (2004) identified three major supra-sectional groups. The largest of these lineages consisted of four subclades, i.e. two directly corresponding to traditional sections Opulus (circumboreal) and Tinus (Eurasia); one containing Oreinotinus section (Latin America) plus the purple-fruited New World members of Odontotinus section, and one consisting of predominantly red-fruited Old World Odontotinus species, purple-fruited New World Viburnum acerifolium species, and Viburnum cylindricum of Megalotinus section (Asia). The second supra-sectional lineage included Viburnum plicatum of Tomentosa section (Asia) and the clade containing most representatives of Solenotinus section (Asia). In the third supra-sectional lineage, the clade corresponding to Pseudotinus section (North America and Asia) was sister to the one containing Lentago section (North America) and the core group of species from Viburnum section (Eurasia).

In our study, the RAPD- and ISSR- based dendrograms clustered Viburnum accessions in five main groups. Comparison of the two dendrograms showed that only $V$. dilatatum and $V$. hillieri and also $V$. plicatum 'Watanabe' and $V$. plicatum f. tomentosum belong to the same cluster. However, similarity observed among Viburnum genotypes on the basis of the RAPD (42\%) and ISSR (31\%) analysis was low. This evaluated diversity was sufficient to distinguish Viburnum genotypes individually with specific bands and banding patterns. The correlation coefficient between the RAPD and ISSR analysis was low $\left(\mathrm{r}=0.305^{*}\right)$, yet statistically significant, which confirms that it was possible to describe a similar range of variability with the use of both the RAPD and ISSR technique. What is more, the low value of the correlation coefficient with a high level of significance might be due to the fact that PCR-amplified profiles in the two marker assay originated from different repetitive and non-repetitive regions of the genomes, and/or background noise due to non-homologous co-migrating band amplification, and/or error in scoring complex banding patterns, which could have possibly influenced the results.

Our results showed great genetic variability among the genotypes of Viburnum obtained from the Dendrological Garden in Przelewice. RAPD and ISSR of the two-marker system applied in the present study were used as effective tools for evaluating genetic similarity and selecting the core collection to enhance efficiency of germplasm management for use in Viburnum breeding and conservation.

\section{Conclusions}

Twenty-three RAPD primers produced a total of 690 loci, of which 271 (39\%) were polymorphic and 418 $(60.9 \%)$ - genotype-specific. The ISSR analysis produced 418 loci, of which 232 (55.5\%) were polymorphic and 186 (44.5\%) - genotype-specific. The UPGMA clustering of genotypes was similar when RAPD- and ISSR- derived dendrograms were compared. Genetic similarity between the examined objects ranged from 6 to $42 \%$ for RAPD matrices, and from 6 to $31 \%$ for ISSR matrices. The Mantel test between two similarity matrices of the markers revealed low, but significant, correlation $\left(\mathrm{r}=0.305^{\circ}\right)$. At the same time, significance of the coefficient suggests that it is possible to describe the same range of variability with the use of both the RAPD and ISSR technique. Randomly amplified polymorphic DNA (RAPD) and inter simple sequence repeat (ISSR) markers are useful tools to detect DNA polymorphism among thirteen Viburnum species of wide geographical distribution obtained from the Dendrological Garden in Przelewice.

\section{References}

Ackerly DD, Donoghue MJ (1998). Leaf size, sapling allometry, and Corner's rules: a phylogenetic study of correlated evolution in maples (Acer). American Nature 152:767-791.

Bugała W (2000). Drzewa i krzewy. PWRiL Warszawa 273-274.

Buntjer JB (2001). PhylTool 1.32. (Phylogenetic Computer Tools). Laboratory of Plant Breeding Wageningen Agricultural University, The Netherlands.

Czembor PC, Arseniuk E (2000). Segregation and recombination of PCR based markers in sequel progeny of Phaeosphaeria species. Mycol Research 104:919-926. 
Donoghue MJ (1983). A preliminary analysis of phylogenetic relationship in Viburnum (Caprifoliaceae s.l.). Systematic Botany 8:45-58.

Donoghue MJ, Baldwin BG (1993). Phylogenetic analysis of Viburnum based on ribosomal DNA sequences from the internal transcribed spacer regions. American Journal of Botany 80:146.

Donoghue MJ, Sytsma K (1993). Phylogenetic analysis of Viburnum based on chloroplast DNA restriction-site data. American Journal of Botany 80:146.

Donoghue MJ, Baldwin BG, Li J, Winkworth RC (2004). Viburnum phylogeny based on chloroplast trnK intron and nuclear ribosomal ITS DNA sequences. Systematic Botany 29:188-198.

Gajera HP, Tomar RS, Patel SV, Viradia RR, Golakiya BA (2011). Comparison of RAPD and ISSR markers for genetic diversity analysis among different endangered Mangifera indica genotypes of Indian Gir forest region. Journal of Plant Biochemistry and Biotechnology 20:217-223.

Gillings M, Holley M (1997). Amplification of anonymous DNA fragments using pairs of long primers generates reproducible DNA fingerprints that are sensitive to genetic variation. Electrophoresis 18:1512-1518.

Godwin ID, Aitken AB, Smith LW (1997). Application of inter simple sequence repeat (ISSR) markers to plant genetics. Electrophoresis 18:1524-1528.

Grimm GW, Renner SS, Stamatakis A, Hemleben VA (2006). Nuclear ribosomal DNA phylogeny of Acer inferred with maximum likelihood, splits graphs, and motif analysis of 606 sequences. Evolution Bioinformatic Online 2:279-294.

Kumar P, Gupta VK, Misra AK, Modu DR, Pandey BK (2009). Potential of molecular markers in plant biotechnology. Plant Omics Journal 2:141-162.

Lobstein A, Weniger B, Malécot V, Um BH, Alzate F, Alton R (2003). Polyphenolic content of two Columbian Viburnum species (Caprifoliceae). Biochemical Systematic and Ecology 31:95-97.

Mantel N (1967). The detection of disease clustering and generalized regression approach. Cancer Research 27:209-220.

Nei M, Li WH (1979). Mathematical model for studying genetic variation in terms of restriction endonucleases. Proceedings of the National Academy of Science of the USA 76:5269-5273.

Pfosser MF, Guzy-Wróblewska J, Sun BY, Stuessy TF, Sugawara T, Fujii N (2002). The origin of species of Acer (Sapindaceae) endemic to Ullung island, Korea. Systematic Botany 27:351367.
Poczai P, Hyvönen J (2010). Nuclear ribosomal spacer regions in plant phylogenetics: problems and prospects. Molecular Biology Report 37:1897-1912.

Sharma SN, Kumar V, Mathur S (2009). Comparative analysis of RAPD and ISSR markers for characterization of sesame (Sesamum indicum L.) genotypes. Journal of Plant Biochemistry and Biotechnology 18:37-43.

Shneyer VS (2009). DNA barcoding is a new approach in comparative genomics of plants. Russian Journal of Genetic 45:1267-1278.

Smolik M, Ochmian I, Grajkowski J (2010), Genetic variability of Polish and Russian accessions of cultivated blue honeysuckle (Lonicera caerulea L.). Russian Journal of Genetic 46:960-966.

Smolik M, Krzysztoszek O (2010). Evaluation of genetic variability in chosen apple (Malus $\times$ domestica Borkh.) cultivars by ISSRPCR analysis. Russian Journal of Genetics 47:819-827.

Souframanien J, Gopalakrishna T (2004). A comparative analysis of genetic diversity in blackgram genotypes using RAPD and ISSR markers. Theoretical Applied Genetic 109:1687-1693.

Suh Y, Heo K, Park Ch (2000). Phylogemetic relationship of Maples (Acer L; Aceraceae) implied by nuclear ribosomal ITS sequences. Journal of Plant Research 113:193-202.

Van de Peer Y, De Wachter R (1994). TREECON for Windows: a software package for the construction and drawing of evolutionary trees for the Microsoft Windows environment. Computer Applied Bioscience 10:569-570.

Williams JGK, Kubelik KA, Livak RJ, Rafalski JA, Tingey SV (1990). DNA polymorphisms amplified by arbitrary primers are useful as genetic markers. Nuclear Acids Research 18:65316535.

Winkworth RC, Donoghue MJ (2004). Viburnum phylogeny: evidence from the duplicated nuclear gene GBSSI. Molecular of Phylogenetic Evolution 33:109-126.

Winkworth RC, Donoghue MJ (2005). Viburnum phylogeny based on combined molecular data: implications for taxonomy and biogeography. American Journal of Botany 92:653-666.

Yüzbaşioğlu E, Hahci MG, Karabacak M, Aksoy A (2011). RAPD and ISSR markers indicate high genetic variation within Lobathallia radiosa in Turkey. Mycol Progress 10:219-228.

Zietkiewicz E, Rafalski A, Labuda D (1994). Genome fingerprinting by Simple sequence repeat (SSR) - anchored polymerase chain reaction amplification. Genomics 20:176-183. 